\title{
Organochlorines in small lakes of the Bolshezemelskaya tundra
}

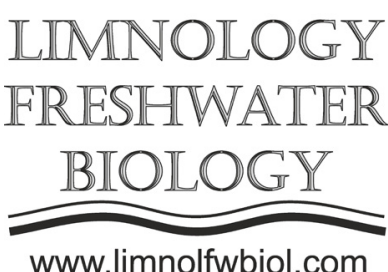

\author{
Shvetsova N.V.*, Koroleva T.A. \\ N. Laverov Federal Center for Integrated Arctic Research of the Ural Branch of the Russian Academy of Sciences, Northern Dvina
} Emb., 23, Arkhangelsk, 163000, Russia

\begin{abstract}
In this study we compared the total amount of organochlorine compounds in the bottom sediments of thermokarst small lakes of the Bolshezemelskaya tundra. The amount of organochlorine compounds in the studied water ecosystems was determined by the value of the non-specific sumparameter $\mathrm{Cl}_{\text {org }}$ (total organically bound chlorine) used for solid natural and technogenic matrices. It was shown that the amount of organically bound chlorine in the upper layers of lake sediments depends on the additive influence of various factors, including the specific properties of intrabasin processes and sedimentation in the water ecosystem, lithological characteristics of bottom sediments, possible impact of the anthropogenic component in the catchment areas and long-range atmospheric transport.
\end{abstract}

Keywords: organochlorines, total organically bound chlorine, bottom sediments, small lakes, Bolshezemelskaya tundra

\section{Introduction}

Organochlorine compounds (OCCs) migrating to the subarctic territories with air masses from low latitudes are subjected to bioaccumulation, long-term preservation and bio-enhancement of toxic properties under permafrost conditions. Under global warming conditions, accompanied by decrease in snow cover, melting down of coastal glaciers, the flows of such compounds are increasing. Small lakes, by virtue of their morphological and hydrological features and inclusion in biogeocenoses, are a universal characteristic of the environment state and are "accumulators" of various elements and compounds. The total amount of organochlorine compounds in bottom sediments of water ecosystems can be estimated by the value of a non-specific sum-parameter used for solid natural and technogenic matrices - total organically bound chlorine $\left(\mathrm{Cl}_{\text {org }}\right)$ (Öberg and Bastviken, 2012).

In this paper, the study objects were presented by two groups of small lakes of the Bolshezemelskaya tundra (Nenets Autonomous Okrug) differing in the level of anthropogenic load. The small lakes BZT-1 and BZT-2 geographically located in an inaccessible area on the eastern border of the Bolshezemelskaya tundra, in the territory of the hydrothermal Pyvmashor natural boundary. The territory of natural boundary belongs to the Adzva river basin and the northernmost location of the exit of thermal-mineral springs of the continental Europe. Small lake BZT-1 is located in the valley of the natural boundary, on the right bank of the Pymvashor stream. Small lake BZT-2 is located in the adjacent territory, downstream the Pymvashor stream, in a small depression with a diameter of about $400 \mathrm{~m}$. Small lakes BZT-3 and BZT-4 are located in the Kolva river basin, $5 \mathrm{~km}$ north-east from Khorey-Ver village. Three oil fields are developed $60 \mathrm{~km}$ north-west of KhoreyVer, therefore this territory falls into the industrial development area with a developed infrastructure complex (Shumilova, 2009).

\section{Materials and methods}

Samples of bottom sediments (BS) were taken by employees of the N. Laverov Federal Center in 20092010 during the work of a combined expedition using a bottom grab. The research materials come from the upper $(0-10 \mathrm{~cm})$ layers of $\mathrm{BS}$. The $\mathrm{Cl}_{\text {org }}$ determination method is based on high-temperature combustion (950$1000^{\circ} \mathrm{C}$ ) of the sample in an oxygen stream followed by microcoulometric titration of chloride ions using the Multi X 2500 analyzer (Analytik Jena AG, Germany) released in accordance with DIN 38414 (part 17). Elemental analysis (specifically $\mathrm{C}_{\text {org }}$ ) was carried out using the Euro EA 3000 automatic elemental analyzer (Eurovector).

\section{Results}

\subsection{Material Composition}

Bottom sediments of small lakes BZT-1 and BZT-2 are characterized as peaty, mainly represented 
Table 1. The $\mathrm{Cl}_{\text {org }}$ value and $\mathrm{Cl}_{\text {org }} / \mathrm{C}_{\text {org }}$ ratio in lake sediments

\begin{tabular}{|c|c|c|c|c|}
\hline Study area & Lake & $\begin{array}{c}\mathrm{C}_{\text {org }}, \\
\%\end{array}$ & $\begin{array}{c}\mathrm{Cl}_{\text {org }}, \\
\mu \mathrm{g} \mathrm{Cl} / \mathrm{g}\end{array}$ & $\begin{array}{c}\mathrm{Cl}_{\text {org }} / \mathrm{C}_{\text {org }}, \\
\mu \mathrm{g} \mathrm{Cl} / \mathrm{C} \mathrm{C}_{\text {org }}\end{array}$ \\
\hline Pymvashor natural boundary & BZT-1 & 45,91 & 326 & 710 \\
Kolva River Basin & BZT-2 & 38,40 & 243 & 633 \\
& BZT-3 & 1,63 & 115 & 7055 \\
\hline
\end{tabular}

by aleuritic-pelitic muds with a high content of $\mathrm{C}_{\text {or }}$ (averaging 42.2\%). Bottom sediments of small lakes BZT-3 and BZT-4 are represented by medium and thin sands of marine origin with a low content of $\mathrm{C}_{\text {org }}$ (on average $0.94 \%$ ).

\subsection{Distribution}

In the upper layers of lake sediments of the Pyvmashor natural boundary the average $\mathrm{Cl}_{\text {org }}$ value is three times higher than in the lakes of the Kolva river basin. Nevertheless, the $\mathrm{Cl}_{\text {org }} / \mathrm{C}_{\text {org }}$ ratio in lake sediments of Kolva river basin was higher by the factor of 10-100 (Table 1).

\section{Discussion}

The higher $\mathrm{Cl}_{\text {org }}$ value in BS of the small lakes of the Pyvmashor natural boundary is due to the lithological characteristics of the sediments, aleuritic-pelitic mud, which creates a favorable habitat for microorganisms that produce OCCs. At the same time, the maximum amount of OCCs adsorbed by organic matter was noted for BS of small lakes of the Kolva River Basin, mainly represented by sands, material with a poor $\mathrm{C}_{\text {org }}$ content and generally low absorption capacity. Under conditions of very low organic matter content (averaging $\mathrm{C}_{\text {org }} 0.94 \%$ ) in the BS of small lakes BZT-3 and BZT-4, the $\mathrm{Cl}_{\text {org }} / \mathrm{C}_{\text {org }}$ ratio was 7055-29600 $\mu \mathrm{g} \mathrm{Cl} / \mathrm{g}$ $\mathrm{C}_{\text {org }}$ in contrast to $730-633 \mu \mathrm{g} \mathrm{Cl} / \mathrm{g} \mathrm{C}_{\text {org }}$ for small lakes BZT-1 and BZT-2 (Table 1). The data obtained allow us to talk about the possible impact of anthropogenic load on water ecosystems from the development of oil fields in the nearby territory of the Kolva River Basin (Tentyukov, 2016)

\section{Conclusions}

In general, the obtained research results suggest that the amount of organically bound chlorine in the bottom sediments of all studied thermokarst small lakes is due to the additive influence of various factors, including the features of intrabasin processes and sedimentation in the water ecosystem, lithological characteristics of bottom sediments, and possible impact of the anthropogenic component in the catchment areas and long-range atmospheric transport.

\section{Acknowledgments}

The authors thank all employees of the $\mathrm{N}$. Laverov Federal Center for Integrated Arctic Research (Arkhangelsk) who participated in the expeditionary work for bottom sampling and transportation of samples and for data on the organic carbon content in sediment samples.

This work was carried out at the expense of Minobrnauki of Russia, project No. AAAA-A18-118012390167-1.

\section{Reference}

Öberg G., Bastviken D. 2012. Transformation of chloride to organic chlorine in terrestrial environments: variability, extent, and implications. Critical Reviews in Environmental Science and Technology 42: 2526-2545. DOI: 10.1080/10643389.2011.592753

Shumilova A.N. 2009. Ekologo-geograficheskoye obosnovaniye perspektiv razvitiya neftegazovoy promyshlennosti Nenetskogo avtonomnogo okruga [Ecological and geographical substantiation of the prospects for the development of the oil and gas industry of the Nenets Autonomous Okrug]. Cand. Sc. Dissertation, South Federal University, Rostov-on-Don, Russia. (in Russian)

Tentyukov M.P. 2016. Ecogeochemistry of industrial development areas of the Bolshezemelskaya tundra and Yamal. Dr. Sc. Dissertation, National Research Tomsk Polytechnic University, Tomsk, Russia. (in Russian) 